\title{
Genomic Variations of SARS-CoV-2 and Effect of Various Factors on COVID-19
}

\section{IJCRR}

Section: Healthcare

Sci. Journal Impact

Factor: 6.1 (2018)

ICV: 90.90 (2018)

(c) (7) (8)

Copyright@IJCRR

\section{Anju Rani ${ }^{1}$, Rajyavardhan Arya ${ }^{2}$, Pradeep Kumar Sharma ${ }^{3}$}

'Department of Life Sciences, Graphic Era Deemed to be University, Dehradun-248002, India; '20uality Assurance Department, Pure and Cure Healthcare Pvt. Ltd, Haridwar, India-249403; '3epartment of Environment Sciences, Graphic Era Deemed to be University, Dehradun-248002, India.

\section{ABSTRACT}

Introduction: COVID-19 (SARS-CoV-2) is a disease caused by the newly discovered novel Coronavirus. The first case of SARS-CoV-2 was reported in Wuhan, China in December 2019 which later turned out pandemic affecting large population across the world till now.

Aim: This study aimed to review morphological differences of SARS-CoV-2 with other viruses belongs to beta coronaviruses and to analyze the effect of various factors on the spread of disease.

Conclusion: SARS-CoV-2 causes a severe acute respiratory illness with morbidity rate up to $3 \%$. Despite $79 \%$ similarity with SARS-CoV, key differences have been observed in spike glycoprotein, 2 accessory proteins and 2 non- structural proteins (nsp). High transmissibility of SARS-CoV-2 across the globe may be associated with these genetic differences. However, geographical differences in cases also suggest the influence of natural immunity, climatic conditions on disease spread. Unavailability of an effective vaccine and antiviral therapy left only social distancing and lockdown as an option to minimize disease spread. Further investigations are needed to know the mode of transmission, resistance to environmental factors. The developments of vaccine for SARS- CoV-2 in many countries are in Phase II \& III of clinical trial whereas many drugs have been repurposed to check their efficacy in combating SARS- CoV-2 infections. .

Key Words: SARS-COV-2, COVID-19, Spike glycoprotein, Climate, Social distancing

\section{INTRODUCTION}

Coronaviruses (CoVs) are important pathogens for human and vertebrates. They can infect the respiratory, gastrointestinal, hepatic, and central nervous system of human, livestock, birds, bat, mouse, and many other wild animals. Coronavirus has become a term everyone is well aware across the world. Coronaviruses $(\mathrm{CoV})$ belong to the family Coronaviridae, order- Nidovirales. The family has four genera .i.e Alphacoronavirus, Betacoronavirus, Deltacoronavirus and Gammacoronavirus. Alpha and Beta coronaviruses have gene sources from bats and rodents while Delta and Gamma Coronaviruses have from avian species. The genus Betacoronavirus is classified into four groups; Betacoronavirus group A, Betacoronavirus group B, Betacoronavirus group C and Betacoronavirus group $\mathrm{D}^{1}$. Coronaviruses are zoonotic pathogens that are present in humans and various animals. The animal host includes dogs, cats, camel, pig, cow, horse, mouse and few birds. Till now seven human coronaviruses (HCoVs) are known capable of infecting humans (Fig.1). All seven human coronaviruses (HCoV-OC43, HCoV-HKU1, HCoV-229E, HCoV-NL63, SARS- CoV, MERS- CoV and SARS-CoV-2) belong to genus Betacoronaviruses. Among seven human Coronaviruses, HCoV-229E, HCoV-NL63 belongs to Betacoronavirus group $\mathrm{A}, \mathrm{HCoV}-\mathrm{OC} 43$ and $\mathrm{HCoV}$ HKU1belongs to group B while SARS- CoV, MERS- CoV and SARS-CoV-2 (COVID-19) belongs to Group B \& C. Human Coronaviruses can cause mild respiratory infections like common cold to severe life taking respiratory illness ${ }^{2}$.

Before the emergence of SARS-CoV-2 pandemic, two other human coronavirus outbreak (SARS and MERS) occurred globally in the year 2003 and 2012 respectively. Severe acute respiratory syndrome (SARS) was firstly noticed in the Guangdong State of China. The disease rapidly spread worldwide before the epidemic was restricted in 2003, after

\section{Corresponding Author:}

Dr. Anju Rani, Department of Life Sciences, Graphic Era Deemed to be University, Dehradun-248002, India; Contact: +91-9870962931; Email: anju.teotia@gmail.com; anju.rani@geu.ac.in

ISSN: 2231-2196 (Print)

Received: 24.08 .2020
ISSN: 0975-5241 (Online)

Revised: 27.09 .2020
Accepted: 24.10 .2020

Published: 03.11.2020 
over 8000 cases and several 800 deaths in 29 countries with a mortality rate around $10 \%{ }^{3}$. The epidemiological and genetic studies suggested that SARS was a zoonotic disease and that coronavirus evolved from a coronavirus that naturally infects Himalayan palm civets.

Middle East Respiratory Syndrome (MERS), another fatal respiratory disease outbreak occurred in 2012, with its origin in Saudi Arabia. It affected 2494 people and caused 858 deaths with a mortality rate of $37 \% \%^{3,4}$. A similar virus came out and spread in South Korea in 2015, with infections primarily being associated with hospitals and healthcare persons. In case of MERS outbreak, dromedary camels worked as an intermediate host in the transmission of viruses to human with the bat as a reservoir host $t^{5}$.

Recently an outbreak of new coronavirus was reported in Wuhan, China at the end of December 2019. Studies report$\mathrm{ed}^{6}$ that novel virus belongs to a beta group of coronaviruses and ICTV named this novel virus as SARS $-\mathrm{CoV}-2$ on account of its similarity $(79 \%)$ with SARS-CoV ${ }^{7}$.

\section{MORPHOLOGY AND GENOMIC VARIATION OF SARS-COV-2}

Coronaviruses are enveloped, positive-sense RNA $(\approx 30 \mathrm{~Kb}$ size) viruses ranging from $60 \mathrm{~nm}$ to $140 \mathrm{~nm}$ in diameter. The presence of glycoprotein spikes on its surface gives it a crown-like appearance and therefore it is named as a coronavirus (In Latin Coronum means crown) [Fig.2]. Coronaviruses possess characteristic club-shaped spikes composed of trimers ${ }^{8}$. Some beta coronaviruses also contain a second fringe of shorter spikes made up of hemagglutinin- esterase (HE). The genomic RNA of coronaviruses vary from 26,000 and 32,000 bases and 6 to 11 open reading frames (ORFs) [6]. The genomic RNA is 5'capped and 3' polyadenylated and is used as a template to translate polyprotein $\mathrm{pp} 1 \mathrm{a} / \mathrm{pp} 1 \mathrm{ab}$. The first ORF represents about $67 \%$ of the whole genome encodes non-structural proteins $\left(\mathrm{nsp}_{\mathrm{s}}\right.$ ) while the remaining ORFs ( $33 \%$ of the genome) at $3^{\prime}$ end encode accessory proteins and four structural proteins ${ }^{9}$. The Structural proteins include spike glycoprotein (S), envelope (E), membrane (M) and nucleocapsid $(\mathrm{N})$ protein.

The genome size of SARS CoV-2 is $29.8 \mathrm{~Kb}$ and genome annotation revealed that it has 14 ORFs that encodes 27 proteins. Similar to other beta coronaviruses, the largest gene orflab at $5^{\prime}$ end of the genome encodes ppla and pplab proteins (Fig.3). The ppla and pplab proteins consist of 15 nonstructural proteins, ppla protein contains $10 \mathrm{nsp}_{\mathrm{s}}$ (nsp1 to nsp10) while pp1ab contains $5 \mathrm{nsp}_{\mathrm{s}}$ (nsp12 to nsp16). In case of SARS CoV-2, nsp3 and nsp2 showed 102 and 61 amino acid substitutions ${ }^{6}$.

The novel SARS CoV-2 stain also consists of four structural proteins i.e spike (S), envelope (E), membrane (M) and nucleocapsid $(\mathrm{N})$ protein ${ }^{10}$. Among the four structural proteins, the spike surface glycoprotein plays a vital role in binding to host cell receptors and the determination of host selection and initiation of the infection cycle. Although spike protein binds to angiotensin-converting enzyme-2 (ACE-2) receptor on host cell analogous to SARS-CoV, various studies have revealed variations in SARS-CoV-2 spike protein ${ }^{11,12}$. Total 27 amino acids substitutions were observed in spike protein, which included 6 amino acid substitutions in Receptor binding domain, 6 substitution in underpinning subdomain and 4 substitutions in the $\mathrm{C}$-terminal domain in RBD of S1 domain ${ }^{6}$. The S2 domain of SARS CoV-2 needed for cell membrane fusion showed approximately $93 \%$ sequence identity with bat-SL-CoVZC45 and bat-SL-CoVZXC21, bat derived viruses in comparison to only $68 \%$ similarity in $\mathrm{S} 1$ domain. The S protein SARS CoV-2 showed $76 \%$ similarity with SARS-CoV, whereas genome similarity was observed to be $79 \%{ }^{7}$. In another study, 6 RBD amino acids are crucial for binding to ACE2 receptors and decisive for the host range of SARS-CoV-like viruses. Out of these six residues, five were found to be at variance between SARS CoV- 2 and SARS-CoV. ${ }^{11}$. These amino acid substitutions in spike protein may account for higher (10-20 times) binding affinity of $\mathrm{S}$ protein to ACE2 receptor when compared to SARS-CoV, which in turn could be the reason of higher transmissibility of COVID-19 ${ }^{13,14}$.

The membrane protein $(\mathrm{M})$ being the most abundant structural protein (218-263 amino acids), contains 3 transmembrane domain and plays an important role in the regeneration of virus within the cell ${ }^{15}$. Moreover glycosylation of $M$ proteins in Golgi apparatus ${ }^{16,17}$ is essential for fusion of virus into cell and to make protein antigenic. The presence of envelope (E) protein, a small structural protein (76-109 amino acids) is required for assembly and morphogenesis of virions and therefore plays a crucial role in viral pathogenesis $^{18}$. The nucleocapsid protein $(\mathrm{N})$ contains two domains (349-470 amino acids) which bind to genomic RNA. The nucleocapsid protein performs various functions like the packaging of the genome into the virion, IFN antagonist and repressor of RNA interference thus facilitate smooth replication of virus ${ }^{17}$. Studies carried out by so far have not found significant variation in $\mathrm{M}, \mathrm{E}$ and $\mathrm{N}$ protein of SARS-CoV-2 when compared with SARS-CoV. The M, E \& N protein of SARS-CoV-2 showed $90.1 \%, 94.7 \%$ and $90.6 \%$ similarity with SARS-CoV, while only $39.2 \%, 34.1 \%$ and $45.9 \%$ similarity was observed with MERS corresponding proteins respectively ${ }^{19}$.

The 3' end of SARS-CoV-2 genome also contains eight accessory proteins (3a, 3b, p6, 7a, 7b, 8b, 9b, and orf14). Previous studies have suggested their role in modulation of host immune response and pathogenesis ${ }^{20,21}$. The open reading frame $3 \mathrm{~b}$ and 6 functions as antagonists of innate immune by 
obstructing the production of Type 1 IFN. Functions of other accessory protein have been mentioned in Table 2 . In comparison with SARS- $\mathrm{CoV}$, the accessory protein $3 \mathrm{~b}$ and $8 \mathrm{~b}$ of SARS - CoV-2 has shown variations in amino acid length (Table 1). Further accessory protein $8 \mathrm{a}$ was found to be absent in SARS-CoV-2 whereas it possesses orf 14 in addition ${ }^{6}$.

\section{EFFECT OF VARIOUS FACTORS ON THE OCCURRENCE OF COVID-19 AND MORBIDITY RATE}

\section{Blood group}

Previous studies were conducted to find out the susceptibility of SARS-CoV disease with ABO blood group. During the SARS outbreak in 2003, staff in Hong kong Hospital showed low incidence in $\mathrm{O}$ blood group individuals compared to non-O blood group individual ${ }^{22}$. In the line of this study, another cellular model study was carried out by Guillon et al. ${ }^{23}$ to investigate blocking of viral spike glycoprotein binding to host ACE-2 receptor by natural antibodies. The experimental findings suggested that anti-A antibodies particularly inhibited the adhesion of SARS-CoV S protein-expressing cells to ACE2-expressing cell lines.

On the onset of novel coronavirus disease (COVID-19) in 2019, a similar study was carried out in China ${ }^{24}$ with 1775 patients to check out the susceptibility of disease in ABO blood group. Results showed a low risk of disease incidence with blood group $\mathrm{O}$, whereas the maximum risk was associated with blood group ' $\mathrm{A}$ '. The probable mechanism for the same may be due to the presence of natural anti- A antibody in the blood. The possible role of these natural antibodies may be in inhibition of S protein/ACE2-dependent adhesion, blocking virus entry followed by complement-mediated neutralization and in the generation of cytotoxic T-cell response against pathogen ${ }^{25-28}$.

\section{Climate}

Although few studies have been carried out to look at the effect of weather on SARS-CoV-2, yet consensus could not be established in terms of research outcomes. The first study in this regard was carried out by Luo et al..$^{29}$ in which effect of absolute humidity on the transmission rate of COVID-19 was studied. Findings of this study suggested that high temperature and humidity will not necessarily lead to turn down cases. A subsequent study was conducted by $\mathrm{Bu}$ et al. ${ }^{30}$ and optimum conditions for the survival of the SARS-CoV-2 was found to be $19^{\circ} \mathrm{C}$ temperature, $75 \%$ humidity and precipitation below $30 \mathrm{~mm} /$ month. In a similar study ${ }^{31}$ effect of temperature and humidity was studied on the incidence of COVID-19 in China between Jan 20 and Feb 29, 2020. The daily incidence of disease was found to be lowest at $-10^{\circ} \mathrm{C}$ while the maximum was observed at $10^{\circ} \mathrm{C}$ and absolute humidity $\left(7 \mathrm{~g} / \mathrm{mm}^{3}\right)$. With the rise of temperature daily incidences decrease while no association was observed between humidity and incidence. One more study of China posted on $31^{\text {st }}$ March ${ }^{32}$, revealed that increase with every $1^{\circ} \mathrm{C}$ in average temperature $\left(5.04\right.$ to $\left.8.2^{\circ} \mathrm{C}\right)$ and every $1 \%$ in average relative humidity $(67 \%$ to $85.5 \%)$ led to decrease in daily confirmed cases by $36-57 \%$ and $11-22 \%$ respectively. However, these relations were not found steady throughout mainland China. In a recent study from Honk Kong by Chin et al. ${ }^{33}$ stability of SARS-CoV-2 was examined at different temperature with the initial virus concentration of $6.7 \log$ TCID $50 / \mathrm{ml}$. The results showed 0.6 and $3-\log$ unit reduction at $4{ }^{\circ} \mathrm{C}, 22^{\circ} \mathrm{C}$ and $37^{\circ} \mathrm{C}$ on 14 days, 7 days and 1 day incubation time respectively. At $56^{\circ} \mathrm{C}$ and $70^{\circ} \mathrm{C}$ temperature, no virus was detected after $30 \mathrm{~min}$ and 5 min respectively. Arujo and Naimi ${ }^{34}$ suggested that vulnerability of people for SARS-CoV-2 will be highest in warm and cold climate followed by arid climate and least in the tropical climate. According to another study, summer temperature would not reduce the size and duration of SARS-CoV-2 incidences at pandemic level, whereas differences in humidity may be important for endemic infections ${ }^{35}$. The World Health Organization (WHO) also stated that virus can transmit in all areas including hot and humid weather. The debate is also going on across the globe about the mode of transmission of virus airborne versus droplet borne as this would suggest more about the effect of seasonality on virus spread and survivability. Moreover, other studies are underway and will be published soon to resolve this mystery.

\section{Social distancing \& Lockdown}

After the emergence of covid-19 in Wuhan, China, several mitigation measures including aggressive case and contact identification, isolation and management and extreme social distancing were implemented by national Government to tackle the epidemic ${ }^{36}$. Later similar measures were adopted by other countries came into the grasp of this disease. Being a novel disease and uncertainty of many factors like mode of transmission, incubation time, transmission rate, survival time outside host and fatality rate rendered policymaking difficult to alleviate the situation. Among many measures taken, social distancing proved to be an important factor in reducing transmission of the virus and thus flattening the endemic curve. A mathematical study was carried out in Wuhan, China to observe the effect of physical distancing on outbreak progression ${ }^{37}$. Results predicted that restrictions on activities till April may help in delaying epidemic peak in Wuhan and early removal of restrictions may lead to second peak before time. COVID-19 spreads through direct contact between two individuals and thus transmits through population rapidly. Social distancing and lockdown strategy was aimed to reduce the size of the epidemic by limiting population mixing. Further, as per the report of WHO-China Joint 
Mission on COVID-19, excessive physical distancing measures such as school and workplace shutdown, and preventing of public crowding all at once may result in increases in households cases. One study also reviewed the effectiveness of school closure in COVID-19 outbreak ${ }^{38}$. Most of the affected countries implemented school closure because of the gravity of the disease. All these speculations were made based on previous pandemics of diseases like SARS, MERS and Influenza. However, according to Viner et al. ${ }^{38}$ modelling study, school closure would account the prevention of $2-4 \%$ of deaths only in case of COVID-19. Undoubtedly implementation of social distancing and lockdown resulted in the slow progression of disease across the globe (Fig. 4). The COVID-19 worst affected countries showed $6 \%$ to $39.6 \%$ decrease in the average daily rate of growth in cases after 3 weeks lockdown in comparison to before lockdown conditions $^{39,40}$

\section{Age, Gender and underlying diseases}

Available data on COVID-19 cases suggested the lowest cases in children than elderly people. As per data from China, no morbidity has been reported under the age of 9 whereas only $0.2 \%$ fatality rate was observed in the age group of 10 19. The US States showed $0.04 \%$ of total deaths in the age group of 0-17 years ${ }^{41}$. A similar pattern was observed in India also $^{42}$. Although lower numbers of cases have been reported in children yet it is not clear that if they are less susceptible or express mild symptoms of the disease. Moreover, the low occurrence of co-morbid diseases in children may be another factor.

The death rate was found to be augmented with increasing age as people of age group $60-80$ has death rate range $23 \%$ to $47.7 \%$. Further people with a pre-existing illness such as diabetes, cardiovascular disease, cancer, respiratory disease and hypertension put people at more risk of dying. Though men and women showed an equal number of cases, yet genderbased vulnerability was also observed in COVID-19 cases $^{43}$. The data of 15 countries (Fig. 5) showed mortality rate in men 1.3 to 3 times higher than women ${ }^{44}$. Assumptions made for same includes higher smoking, drinking habits in men leads to co-morbid diseases, less exposure to women due to cultural, societal and work nature. A study of 331 COVID-19 patients was undertaken by Zeng et al. ${ }^{45}$ in Wuhan China to compare the difference of SARS-CoV-2 IgG antibody between male and female. The results evidenced a higher level of IgG antibodies in female than male patients. Further generation of $\operatorname{IgG}$ antibodies was found to be augmented in the early stage of disease in females.

\section{Treatment}

No effective treatment therapy has been developed for novel emerged COVID-19 disease caused by SARS-CoV-2 till now. Most of the SARS-CoV-2 critical patients have been given rescue treatment with oxygen support and convalescent plasma and immunoglobulin $G$ therapy ${ }^{54,55}$. Several therapeutic strategies such as plasma therapy, monoclonal antibodies, intravenous immunoglobulins, combinatorial therapy and repurposing of drugs have been explored for SARS-CoV-2 infections $\mathrm{s}^{46,47,48,49}$. Each of these therapies has some drawbacks and in some cases toxicities prevailed over benefits. Interferons (IFN) are known to plan an important role during viral infection by activation of innate immune response. Use of exogenous IFN for treatment of coronaviruses was firstly carried out in $1983^{50}$. In case of SARS-CoV-2, China has carried out trials to treat patients with INF- $\alpha$ and ribavirin as a combination therapy (ChiCTR2000029387) ${ }^{51}$. In another study dose-dependent IFNs inhibited SARS-CoV-2 in two mammalian epithelial cell lines (human Calu-3 and simian Vero E6. The results showed inhibition of SARS-CoV-1 only by IFN-alpha in these cell lines Whereas SARS-CoV-2 displayed a wider IFN sensitivity than SARS-CoV- $1^{52}$. For SARS-CoV-2, limited in vivo studies with IFN has been carried out so far and need further studies to conclude.

Several herbal compounds such as Glycyrrhizin, Baicalin, Escin and Resperine isolated from liquorice roots, Scutellaria baicalensis, horse chestnut and Rauwolfia sps. respectively also showed anti-coronaviral activity ${ }^{53}$. Glycyrrhizin and escin showed antiviral activity against SARS-CoV ${ }^{54,55}$. However, the mechanism of glycyrrhizin against SARS-CoV remained unclear. Baicalin (flavanoid) and risperidone (alkaloid) also showed in vitro antiviral activity against SARS$\mathrm{CoV}^{53}$. Therefore herbal medicines were tested to enhance the immunity against COVID-19. In China, a herbal formula with three herbs Scutellaria baicalensis, honeysuckle, and forsythia used to treat various diseases was also explored for the treatment of COVID-19 in a clinical trial. The preliminary results showed effectiveness yet further studies are required for validation ${ }^{55}$. Further according to Unani traditional system, Jamia Hamdard, NewDelhi recommended use of specific drugs/agents loban (Styrax benzoides W. G. Craib), sandroos (Hymenaea verrucosa Gaertn.), Za'fran (Crocus sativus L.), and vinegar to augment immunity ${ }^{56,57}$. Apart from this, Indian Ayurvedic system suggested few practices such as regular intake of warm water throughout the day, practising breathing exercises \& yoga, steam inhalation use of some spices (black pepper, clove, ginger, turmeric \& garlic), nasally applying oil in alleviating COVID symptoms ${ }^{58}$

Various Nucleoside analogues are known for their antiviral activity. A mechanism for antiviral activity may account for interference in replication, decrease in transcription rate and fidelity etc. It has been found that only some nucleotide inhibitors were able to inhibit replication of coronaviruses. Nucleotide inhibitors such as favipiravir, Remdesivir and ribavirin, have shown in vitro inhibitory activity against SARS-CoV-2. Remdesivir (1'-cyano-substituted adenosine nucleotide) has been found to treat SARS-CoV-2 case suc- 
cessfully in US ${ }^{59}$. Another drug that has been explored for the treatment of SARS-CoV-2 infections is chloroquine/hydroxychloroquine purposed for the treatment of malaria. The mode of action of chloroquine/hydroxychloroquine against SARS-CoV-2 is not very clear and probably works by blocking viral entry into cells by inhibiting glycans linking to host receptors, proteolytic processing, endosomal acidification and immunomodulatory effects $(\downarrow \mathrm{TNF}-\alpha$ and IL- 6 production $)^{47}$. Combination of chloroquine with Remdesivir has been found effective in inhibition of SARS-CoV-2. Similarly, in a study with 6 patients' combination of chloroquine with azithromycin showed better virus clearance (100\%) than chloroquine $(57 \%)$ as a single treatment drug ${ }^{60}$. However, contradictory results have been received for use of chloroquine/hydroxychloroquine for treatment and more studies are required for establishing the relation between drug dosage and toxicity, use of the drug for prophylaxis or post infection treatment ${ }^{60}$. It has also been observed that the use of protease inhibitors lopinavir/ritonavir decreased viral load in SARS-CoV-2 patients in Korea significantly ${ }^{61}$. Ribavirin when used in combination of Lopinavir/Ritonavir reduced chances of acute respiratory distress syndrome in patients in addition to the low mortality rate of virus-infected patients $^{62,63}$. In an open-label trial with lopinavir/ritonavir was given as 400/100 mg orally/12 hours, no improvement has been observed in comparison to standard care ${ }^{64}$.

Few other drugs such as avermectin (antiparasitic) and dexamethasone (corticosteroids) has also shown anti SARSCoV-2 activity ${ }^{65,66}$. However use of steroids in COVID-19 patients was recommended only with supplemental oxygen and artificial ventilation ${ }^{66}$. Plasma therapy is another treatment strategy employed for treatment of SARS-CoV-2. Plasma therapy was initially used for treatment of Ebola and MERS outbreak in year 2014 and 2015 respectively. Plasma therapy works as an alternative treatment when antivirals do not work for an infection. In a study with 10 critical COVID patients by Duan et al. ${ }^{67}$, a single dose of convalescent plasma (200ml) acquired from COVID recovered patients reported neutralizing antibody titers more than 1:640 and $70 \%$ patients became free from viremia. In a study by Shen et al on 5 patients with severe COVID infections, viral load decreased within a few days on the administration of convalescent plasma ${ }^{68}$. These studies open the possibility for the prospective use of convalescent plasma therapy for the treatment of SARS-CoV infected patients. Morphological and genomic studies of SARS-CoV-2 also reported around 66 new targets for drug development and probably will add more therapeutic agents for the treatment of SARS-CoV- $2^{47}$.

\section{Research gaps yet to be addressed}

The COVID-19 has turned out into pandemic with 31,002,904 cases and 961616 deaths till 20th Sep 2020 across the world. The rapidly spreading disease kept governments at their toes to alleviate the situation. The research community is trying hard to uncover the mystery of novel coronavirus. Because of above several studies have already been carried out for COVID-19 for virus morphology, genome structure and variations, survivability in different climatic conditions, the impact of disease in different age groups and gender vulnerability for the disease. However, various research gaps are yet to be filled to connect links. Controversy on origin and evolution is still going on and final stamping is awaited. Although research studies have almost revealed morphology, genome structure and variations in SARS-CoV-2, however, efficient therapeutics agents for treatment are still lacking. Vaccine developments are underway and reached in Phase I, II \& III in many countries. The first vaccine, Sputnik V launched by Russia has shown side effects in about $14 \%$ volunteers. Till the full proof vaccine development for SARS-CoV-2, more studies should be conducted on the repurposing of existing drugs to use as preventive measure or cure. Studies carried out to check the effect of climate on COVID-19 occurrence were modelling based predictions. Results showed variations in outcomes, therefore real scale studies need to be done. The available data also indicated variations in susceptibility to COVID-19 in different blood groups, gender and age group. Limited studies have been reported to validate the results. Little is known about the factors involved (societal, cultural or physiological differences) for the lesser vulnerability of women and children to COVID-19. Uncertainty about the onset of infectiousness and the duration of the infectious period also made the situation difficult to handle. Further contact tracing of mild infection (asymptomatic) and knowing their contribution in transmissibility of disease is the utmost requirement at the moment.

\section{CONCLUSION}

SARS Co-V-2 emerged as a novel coronavirus belongs to betacoronavirus lineage. Structural variations have been observed majorly in spike glycoprotein, and few changes in accessory and nonstructural proteins. Change in spike protein binding capacity probably accounts for its high transmissibility and thus can be targeted for development of vaccine/ antiviral drugs. Characterization and functions of nonstructural proteins and accessory proteins in SARS-CoV-2 are not completely understood. Till now no treatment could be developed for COVID-19 and increasing rate of infections and morbidity is a matter of concern. Social distancing, lockdown and adoption of safety measures such as mask-wearing, use of alcohol-based sanitizers, intake of lukewarm water and vitamin $\mathrm{C}$ rich foods have come out a way to minimize the rate of infection and transmission. Also, lockdown provided time to national and international governments for medical preparedness. Besides social distancing and lockdown, contact tracing, number of tests carried out also played an impor- 
tant role in reducing transmission and death toll. Apart from maintaining low infection level, efforts should be made to increase natural immunity, develop the culture to minimize the occurrence of forthcoming zoonotic diseases.

Author's Contribution: All Authors contributed equally.

\section{ACKNOWLEDGEMENT}

Authors acknowledge the immense help received from the scholars whose articles are cited and included in references to this manuscript. The authors are also grateful to authors/ editors/publishers of all those articles, journals and books from where the literature for this article has been reviewed and discussed

Conflict of Interest: Authors declare that they have no conflict of interest

\section{Source of Funding: Nil}

\section{REFERENCES}

1. Richman DD, Whitley RJ, Hayden FG, eds. Clinical virology, 4th edn. Washington: ASM Press, 2016.

2. MacLachlan NJ, Dubovi EJ, Coronaviridae. In: Fenner's Veterinary Virology, $5^{\text {th }}$ Edition, 2017;435-461, https://doi. org/10.1016/B978-0-12-800946-8.00024-6.

3. Huang $\mathrm{C}$,Wang $\mathrm{Y}, \mathrm{Li} \mathrm{X}$, et al. Clinical features of patients infected with 2019 novel coronavirus in Wuhan, China. Lancet 2020; doi:10.1016/S0140-6736(20)30183-5

4. Memish ZA, Perlmam S, Van Kerkhove MD, Zumla A. Middle East respiratory syndrome. Lancet 2020; 395: 1063-77. https:// doi.org/10.1016/S0140-6736 (19) 33221-0

5. Singhal T. A Review of Coronavirus Disease-2019 (COVID-19). Indian J Pediatr 2020; 87: 281-286

6. Wu A. et al., Genome composition and divergence of the novel coronavirus (2019-nCoV) originating in China. Cell Host \& Microbe 2020; DOI:10.1016/j.chom.2020.02.001, 2020.

7. Lu R, Zhao X, Li J, et al. Genomic characterisation and epidemiology of 2019 novel coronavirus: implications for virus origins and receptor binding. Lancet 2020; 395: 565-74

8. Chen N, Zhou M, Dong X, et al. Epidemiological and clinical characteristics of 99 cases of 2019 novel coronavirus pneumonia in Wuhan, China: a descriptive study. Lancet 2020; DOI:10.1016/S0140-6736(20)30211-7

9. Cui J, Li F, Shi ZL. Origin and evolution of pathogenic coronaviruses. Nat Rev Microbiol 2019; 17: 181-192.

10. Hussain S, Pan J, Chen Y, et al. Identification of novel subgenomic RNAs and noncanonical transcription initiation signals of severe acute respiratory syndrome coronavirus. J Virol 2005; 79(9): 5288-5295.

11. Andersen KG, Rambaut A, Ian Lipkin W, Holmes EC, Garry RF. The proximal origin of SARS-CoV-2. Correspondence, Nature Medicine 2020; https://doi.org/10.1038/s41591-020-0820-9

12. Wu F, Zhao S, Yu B, Chen YM, Wang W, Song ZG, et al. A new coronavirus associated with human respiratory disease in China. Nature 2020, 579: 265-281.

13. Liu C, Zhou Q, Li, Garner LV, Watkins SP, Carter LJ, Smoot J, Gregg AC, Daniels AD, Jervey S, Albaiu D. Research and De- velopment on Therapeutic Agents and Vaccines for COVID-19 and Related Human Coronavirus Diseases. ACS Central Science 2020; DOI: 10.1021/acscentsci.0c00272

14. Wrapp D, Wang N, Corbett KS, Goldsmith JA, Hsieh CL, Abiona O, Graham BS, McLellan JS. Cryo-EM structure of the 2019-nCoV Spike in the prefusion conformation. Science 2020; eabb2507.

15. Mousavizadeh L, Ghasemi S. Genotype and phenotype of COVID-19: Their roles in pathogenesis. J Microbiol Immunol Infect 2020; pii: S1684-1182(20)30082-7. DOI: 0.1016/j. jmii.2020.03.022.

16. de Haan CA, Masters PS, Lili Kuo, Harry Vennema, Peter JM, Rottier. Coronavirus particle assembly: primary structure requirements of the membrane protein. J Virol. 1998; 72: 68386850 .

17. Tok TT, Tatar G. Structures and Functions of Coronavirus Proteins: Molecular Modeling of Viral Nucleoprotein. Int J Virol Infect Dis 2017; 2(1): 001-007.

18. Nieto-Torres JL, DeDiego ML, Verdiá-Báguena C, et al. Severe acute respiratory syndrome coronavirus envelope protein ion channel activity promotes virus fitness and pathogenesis. PLOS Pathog 2014; 10(5):e1004077.

19. Ahmed SF, Quadeer AA, Mckay MR. Preliminary Identification of Potential Vaccine Targets for the COVID-19 Coronavirus (SARS-CoV-2) Based on SARS-CoV Immunological Studies. Viruses 2020; 12 (254): 1-15

20. Narayanan K, Huang C, Makino S. SARS coronavirus accessory proteins. Virus Res 2008; 133: 113-121.

21. Liu DX, Fung TS, Chong KKL, Shukla A, Hilgenfeld R. Accessory proteins of SARS-CoV and other coronaviruses. Antiviral Res 2014; 97-109.

22. Cheng Y, Wong R, Soo YO, Wong WS, Lee CK, Ng MH, Chan P, Wong KC, Leung CB, Cheng G. Use of convalescent plasma therapy in SARS patients in Hong Kong. Eur J Clin Microbiol Infect Dis. 2005; 24(1):44-6.

23. Guillon P, Clément M, Sébille V, Rivain JG, Chou CF, RuvoënClouet N, Le Pendu J. Inhibition of the interaction between the SARS-CoV spike protein and its cellular receptor by anti-histoblood group antibodies. Glycobiology 2008; 18(12):1085-93.

24. Zeng F, Dai C, Cai P, Wang J, Xu L, Li J, Hu G, Wang L. A comparison study of SARS-CoV-2 IgG antibody between male and female COVID-19 patients: a possible reason underlying different outcome between gender. medRxiv preprint 2020; DOI: https://doi.org/10.1101/2020.03.26.20040709

25. St"ager S, Alexander J, Kirby AC, Botto M, Rooijen NV, Smith DF, Brombacher F, Kaye PM. Natural antibodies and complement are endogenous adjuvants for vaccine-induced CD8+ Tcell responses. Nat Med 2003; 9:1287-1292.

26. Neil SJ, McKnight A, Gustafsson K, Weiss RA. HIV-1 incorporates $\mathrm{ABO}$ histo-blood group antigens that sensitize virions to complement-mediated inactivation. Blood 2005; 105:46934699.

27. Keyaerts E, Vijgen L, Pannecouque C, Van Damme E, PeumansW, Egberink H, Balzarini J, Van Ranst M. Plant lectins are potent inhibitors of coronaviruses by interfering with two targets in the viral replication cycle. Antiviral Res 2007; 75:179-187.

28. D"urrbach A, Baple E, Preece AF, Charpentier B, Gustafsson $\mathrm{K}$. Virus recognition by specific natural antibodies and complement results in MHC I cross-presentation. Eur J Immunol 2007; 37:1254-1265.

29. Luo W, Majumder M, Liu D, Poirier C, Mandl K, Lipsitch M, and Santillana M. The role of absolute humidity on transmission rates of the COVID-19 outbreak. medRxiv preprint. 2020; DOI: https://doi.org/10.1101/2020.02.12.20022467 
30. Bu J, Peng DD, Xiao H, Yue Q, Han Y, Lin Y, Hu G, Chen J. Analysis of meteorological conditions and prediction of epidemic trend of 2019-nCoV infection in 2020. medRxiv preprint. 2020; DOI: https://doi.org/10.1101/2020.02.13.20022715

31. Shi P, Dong Y, Yan Y, Li X, Zhao C, Liu W, He M Tang S, $\mathrm{Xi}$ S. The impact of temperature and absolute humidity on the coronavirus disease 2019 (COVID-19) outbreak - evidence from China. medRxiv preprint, 2020, DOI: https://doi. org/10.1101/2020.03.22.20038919

32. Qi H, Xiao S, Shi R, Ward MP, Chen Y, Tu W, Su Q, Wang W, Wang X, Zhang1 Z. COVID-19 transmission in Mainland China is associated with temperature and humidity: A timeseries analysis. medRxiv preprint. 2020; DOI: https://doi. org/10.1101/2020.03.30.20044099

33. Chin et al. Stability of SARS-CoV-2 in different environmental conditions. Lancet Microbe. 2020; https://doi.org/10.1016/ S2666-5247(20)30003-3

34. Araujo MB \& Naimi B. Spread of SARS-CoV-2 Coronavirus likely to be constrained by climate. medRxiv, 2020; 2020.03.12.20034728.

35. Baker RE, Yang W, Vecchi GA, et al. Susceptible supply limits the role of climate in the COVID-19 pandemic. medRxiv. 2020; DOI: $10.1101 / 2020.04 .03 .20052787$.

36. Report of the WHO-China Joint Mission on Coronavirus Disease 2019 (COVID-19)

37. Prem K, Liu Y, Russell TW Kucharski AJ, Eggo RM, Davies $\mathrm{N}$. The effect of control strategies to reduce social mixing on outcomes of the COVID-19 epidemic in Wuhan, China: a modelling study. The Lancet Public Health, 2020; DOI: 10.1016/ S2468-2667(20)30073-6

38. Viner RM, Russell SJ, Croker H, Packer J, Ward J, Stansfield C, Mytton O, Bonell C, Booy R. School closure and management practices during coronavirus outbreaks including COVID-19: a rapid systematic review. Lancet Child Adolesc Health.2020; https://doi.org/10.1016/ S2352-4642(20)30095-X

39. European Centre for Disease Prevention and Control (https:// www.ecdc.europa.eu/en)

40. Ministry of health and family welfare, Government of India (https://www.mohfw.gov.in/)

41. www.worldometer.info, accessed August 23, 2020

42. Gupta R, Pal SK, Pandey G. A Comprehensive Analysis of COVID-19 Outbreak situation in India. medRxiv preprint 2020; DOI: https://doi.org/10.1101/2020.04.08.20058347

43. Wenham C, Smith J, Morgan R. COVID-19: the gendered impacts of the outbreak. Lancet. 2020; Vol. 395 https://doi. org/10.1016/ S0140-6736(20)30526-2

44. www.gobalhealth5050.org/covid19/, accessed August 17, 2020

45. Zeng F, Dai C, Cai P, Wang J, Xu L, Li J, Hu G, Wang L A comparison study of SARS-CoV-2 IgG antibody between male and female COVID-19 patients: a possible reason underlying different outcome between gender. medRxiv preprint 2020; DOI: https://doi.org/10.1101/2020.03.26.20040709

46. Jamshaid H, Zahid F, Ud Din I, Zeb A, Choi HG, Khan GM, Ud Din F.Diagnostic and Treatment Strategies for COVID-19. AAPS PharmSciTech 2020; 21:222.

47. Wang D, Hu B, Hu C, Zhu F, Liu X, Zhang J., et al. Clinical characteristics of 138 hospitalized patients with 2019 novel coronavirus-infected pneumonia in Wuhan, China. JAMA. 2020

48. Wu A. et al. Genome composition and divergence of the novel coronavirus (2019-nCoV) originating in China. Cell Host \& Microbe 2020; DOI:10.1016/j.chom.2020.02.001, s2020

49. Wu CY, Jan JT, Ma SH, Kuo CJ, Juan HF, Cheng YS, Hsu HH, Huang HC, Wu D, Brik A, Liang FS, Liu RS, Fang JM, Chen ST, Liang $\mathrm{PH}$, Wong $\mathrm{CH}$. Small molecules targeting severe acute respiratory syndrome human coronavirus, Proc. Natl. Acad. Sci. USA, 2004; 101: 10012.

50. Stroher U, DiCaro A, Li Y, Strong JE, Aoki F, Plummer F, Jones SM, Feldmann H. Severe acute respiratory syndrome-related coronavirus is inhibited by interferon-alpha. J Infectious Diseases 2004; 189: 1164-1167.

51. Registry CCT. Comparative effectiveness and safety of ribavirin plus interferon-alpha, lopinavir/ritonavir plus interferon-alpha and ribavirin plus lopinavir/ritonavir plus interferon-alphain in patients with mild to moderate novel coronavirus pneumonia. http://www.chictr.org.cn/showprojen.aspx?proj048782 2020; Accessed 4 April 2020.

52. Felgenhauer U, Schoen A, Gad HH, Hartmann R, Schaubmar AR, Failing K, Drosten C, \& Weber F. Inhibition of SARS$\mathrm{CoV}-2$ by type I and type III interferons. The Journal of biological chemistry 2020.

53. Pyrc K, Berkhout B, Van der Hoek L. Antiviral Strategies Against Human Coronaviruses. Infectious Disorders - Drug Targets 2007; 7: 59-66.

54. Cinatl J, Morgenstern B, Bauer G, Chandra P, Rabenau H, Doerr HW. Glycyrrhizin, an active component of liquorice roots, and replication of SARS-associated coronavirus. Lancet 2003; 361:2045-6.

55. Ni L, Zhou L, Zhou M, Zhao J, Wen Wang D. Combination of western medicine and Chinese traditional patent medicine in treating a family case of COVID-19 in Wuhan. Front Med 2020;14:210-4.

56. Nikhat S, Fazil M. Overview of COVID-19; its prevention and management in the light of Unani medicine. Sci Total Environ 2020; 728:138859.

57. Parikh DP, Parikh N, Parikh D. Role of homoeopathy in covid-19 management-a clinical experience. Artic World J Pharm Res.2020; 9:2459-66.

58. Rajkumar RP. Ayurveda and COVID-19: Where psychoneuroimmunology and the meaning response meet. Brain Behav Immun 2020. pii: S0889- 1591(20)30637-1.

59. Sanders JM, Monogue ML, Jodlowski TZ, Cutrell JB. Pharmacologic Treatments for Coronavirus Disease 2019 (COVID-19): A Review, JAMA, 2020; DOI:10.1001/jama.2020.6019

60. Arshad S, Kilgore P, Chaudhry ZS, Jacobsen G, Wang DD, Huitsing K, et al. Treatment with hydroxychloroquine, Azithromycin, and combination in patients hospitalized with COVID-19. Int J Infect Dis. 2020; 97:396-403.

61. Ye ZY, Yuan S, Yuen KS, Fung SY, Chan CP, Jin DY. Zoonotic origins of human coronaviruses, Int J Bio Sci 2020; 16: 1686-97.

62. Dong L, Hu S, Gao J. Discovering drugs to treat coronavirus disease 2019 (COVID-19). Drug Discov Ther. 2020; 14(1):58-60.

63. Stockman LJ, Bellamy R, Garner P. SARS: Systematic review of treatment effects. PLoS Med 2006; 3:e343.

64. Qayyumi B, Sharin F, Singh A, Tuljapurkar V, Chaturvedi P. Management of COVID-19: A brief overview of the various treatment strategies. Cancer Res Stat Treat 2020; 3:233-43.

65. Caly L D, Druce G, Catton M A, Jans DM, Wagstaff K. The FDA-approved drug ivermectin inhibits the replication of SARS-CoV-2 in vitro. Antiviral Research. 2020; 'In press, preproof. DOI: https://doi.org/10.1016/j.antiviral.2020.104787.

66. NIH. The National Institutes of Health COVID-19 Treatment Guidelines Panel provides recommendations for dexamethasone in patients with COVID-19. http:/ /www.covid19treatmentguidelines.nih.gov/dexamethasone/(2020). Accessed 8 July 2020.

67. Duan K, Liu B, Li C, Zhang H, Yu T, Qu J, et al. Effectiveness of convalescent plasma therapy in severe COVID-19 patients. Proc Natl Acad Sci U S A 2020;117:9490-6. 
68. Shen C, Wang Z, Zhao F, Yang Y, Li J, Yuan J, et al. Treatment of 5critically ill patients with COVID-19 with convalescent plasma. JAMA 2020; 323:1582-9.

69. Chu CM, Cheng VC, Hung IF, et al; HKU/UCH SARS Study Group. Role of lopinavir/ritonavir in the treatment of SARS: initial virological and clinical findings. Thorax. 2004;59(3):252256. DOI:10.1136/thorax.2003.012658

70. Cao B, Wang Y, Wen D, et al. A trial of lopinavir-ritonavir in adults hospitalized with severe COVID-19. N Engl J Med. Published online March 18, 2020. DOI:10.1056/NEJMoa2001282

71. Kaletra (Lopinavir and ritonavir) [package insert]. North Chicago, IL: Abbvie; 2019. Accessed March 17, 2020. https://www. accessdata.fda.gov/drugsatfda_docs/label/2019/021226s048lbl. pdf

72. NIH. Study to evaluate the safety and antiviral activity of Remdesivir (GS-5734TM) in participants with severe coronavirus disease (COVID-19). http://clinicaltrials.gov/ct2/show/ NCT04292899, 2020. Accessed 4 April 2020.

73. Registry CCT. The efficacy and safety of favipiravir for novel coronavirus-infected pneumonia: a multicenter, randomized, open, positive, parallel-controlled clinical study. http://www. chictr.org.cn/showprojen.aspx?proj050137. 2020.

74. Chen N, Zhou M, Dong X et al. Epidemiological and clinical characteristics of 99 cases of 2019 novel coronavirus pneumonia in Wuhan, China: a descriptive study. Lancet. 2020;395:507513. PMID: 32007143 DOI: 10.1016/S0140-6736(20)30211-7

75. Zhou D, Dai SM, Tong Q. COVID-19: a recommendation to examine the effect of hydroxychloroquine in preventing infection and progression. [published online March 20, 2020]. J Antimicrob Chemother. 2020

76. Devaux CA, Rolain JM, Colson P, Raoult D. New insights on the antiviral effects of chloroquine against coronavirus: what to expect for COVID-19? Int J Antimicrob Agents. Published online March 11, 2020. DOI:10.1016/j.ijantimicag.2020.105938

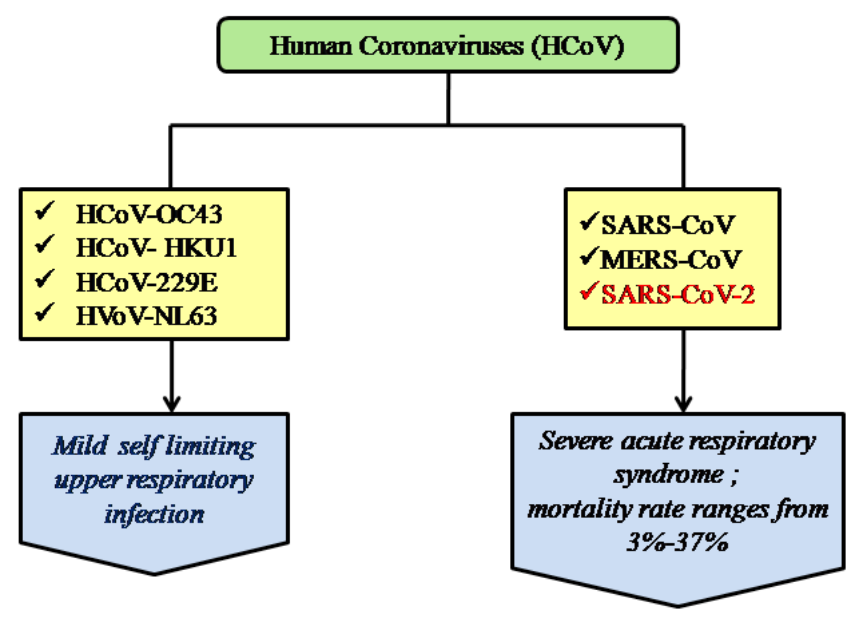

Figure 1: Human Coronaviruses known till date ${ }^{2}$.
77. Colson P, Rolain JM, Lagier JC, Brouqui P, Raoult D. Chloroquine and hydroxychloroquine as available weapons to fight COVID-19. Int J Antimicrob Agents. Published online March 4, 2020. DOI:10.1016/j.ijantimicag.2020.105932

78. Aralen (chloroquine phosphate) [package insert]. Bridgewater, NJ: Sanofi-Aventis; 2008. Accessed March 17, 2020. https:// www.accessdata. fda.gov/drugsatfda_docs/

79. Gautret P, Lagier JC, Parola P, et al. Hydroxychloroquine and azithromycin as a treatment of COVID-19: results of an openlabel non-randomized clinical trial. Int J Antimicrob Agents. Published online March 20, 2020. DOI:10.1016/j. ijantimicag.2020.105949

80. Chen J, Liu D, Liu L, et al. A pilot study of hydroxychloroquine in the treatment of patients with common coronavirus disease-19 (COVID-19). J Zhejiang Univ (Med Sci). Published online March 6, 2020. DOI:10.3785/j.issn.1008-9292.2020.03.03

81. Xu X, Han M, Li T, et al. Effective treatment of severe COVID-19 patients with tocilizumab. China Xiv. Preprint posted March 5, 2020. doi:10. 12074/202003.00026

82. Actemra (tocilizumab) [package insert]. South San Francisco, CA: Genentech, Inc; 2019.Accessed March 17, 2020. https:// www.accessdata.fda.gov/ drugsatfda_docs/label/2019/125276s 127,125472s040lbl.pdf

83. Sanofi. Sanofi and Regeneron begin global Kevzara (sarilumab) clinical trial program in patients with severe COVID-19 [news release]. Published March 16, 2020. Accessed March 18, 2020.

84. Cao W, Liu X, Bai T et al. High-dose intravenous immunoglobulin as a therapeutic option for deteriorating patients with coronavirus disease 2019. Open Forum Infectious Diseases. 2020. PMID: 32258207 DOI: 10.1093/ofid/ofaa102; Sakoulas G, Geriak M, Kullar R et al. Intravenous immunoglobulin (IVIG) significantly reduces respiratory morbidity in COVID-19 pneumonia: a prospective randomized trial. medRxiv. Posted Jul 25, 2020. Preprint (not peer-reviewed). (https://www.medrxiv.org/content/10.1101/2020.07.20.20157891v1).

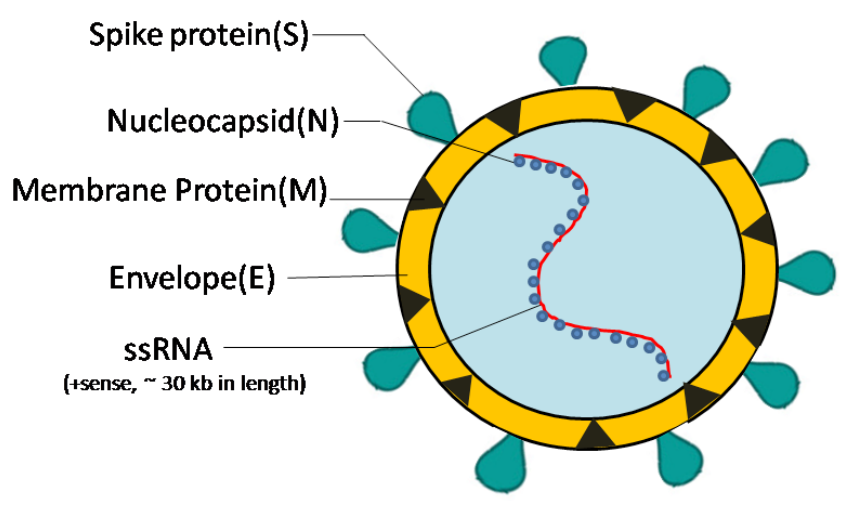

Figure 2: Structure of Coronavirus ${ }^{13}$. 


\section{Amino acid substitutions/change in \\ compared to SARS COV}

Figure 3: Genome organization and variations observed in non-structural protein (nsp), structural protein (S, E, M \& N) and accessory proteins of SARS-CoV-2 in comparison to SARS-CoV. ${ }^{48}$

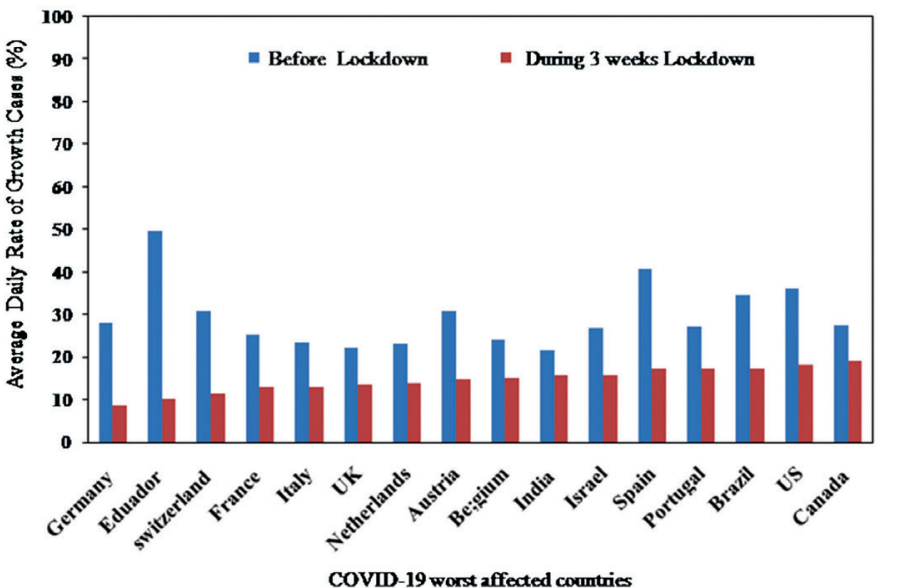

Figure 4: Effect of three weeks lockdown on COVID-19 worst-affected countries. ${ }^{44}$

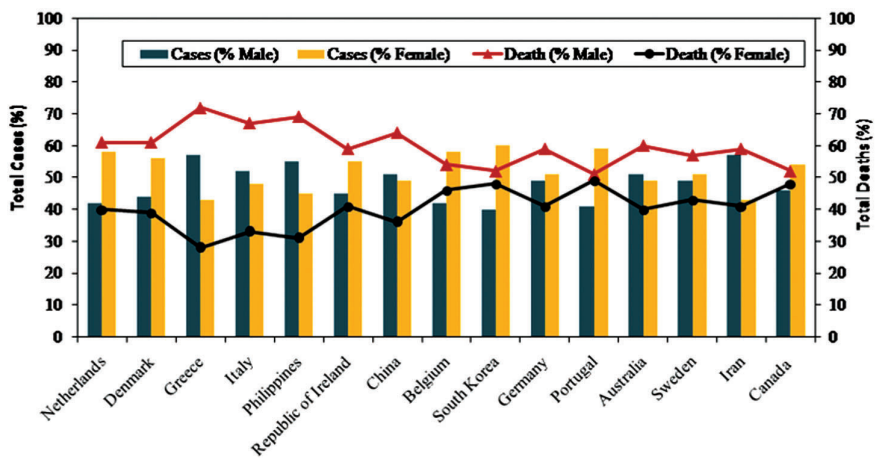

Figure 5: Comparison of \% COVID-19 cases incidence and morbidity rate between male and female in different countries ${ }^{44}$ 
Table 1: Comparison of structural properties of SARS-CoV, MERS-CoV and novel emergent strain SARS-CoV-2 ${ }^{4,21}$

\begin{tabular}{|c|c|c|c|c|}
\hline S. No. & Structural component & SARS-CoV & MERS-CoV & SARS-CoV-2 (COVID-19) \\
\hline 1. & Genome size & $\sim 29.8 \mathrm{~kb}$ & $\sim 30-31 \mathrm{~kb}$ & $\sim 29.8 \mathrm{~kb}$ \\
\hline 2. & ORFs & 14 & 10 & 14 \\
\hline \multirow[t]{5}{*}{3.} & Structural proteins & & & \\
\hline & Spike surface Glycoprotein (S) & $\begin{array}{l}\text { Binds to Angiotensin con- } \\
\text { verting enzyme } 2 \text { (ACE2) } \\
\text { or rarely to GD2096 as } \\
\text { receptor }\end{array}$ & $\begin{array}{l}\text { Binds to dipepti- } \\
\text { dyle peptidase } 4 \\
\text { (DPP4 aka CD26 ) } \\
\text { receptor }\end{array}$ & $\begin{array}{l}\text { Binds to Angiotensin con- } \\
\text { verting enzyme } 2 \text { (ACE2) } \\
\text { receptor }\end{array}$ \\
\hline & Small Envelope protein (E) & Present & Present & Present \\
\hline & Matrix Protein (M) & Present & Present & Present \\
\hline & Nucleocapsid protein $(N)$ & Present & Present & Present \\
\hline \multirow[t]{4}{*}{4.} & Accessory proteins & 3a, 3b, 6, 7a, 7b, 8a, 8b, 9b & $3,4 \mathrm{a}, 4 \mathrm{~b}$, and 5 & 3, 3a, 3b, p6, 7a, 7b, 8b, 9b \\
\hline & & $\begin{array}{l}\text { 3b- Made up of } 154 \text { amino } \\
\text { acids }\end{array}$ & & $\begin{array}{l}3 \text { b- Made up of } 22 \text { amino } \\
\text { acids }\end{array}$ \\
\hline & & $\begin{array}{l}\text { 8b- Made up of } 84 \text { amino } \\
\text { acids }\end{array}$ & & 8a- absent 8b \\
\hline & & & & $\begin{array}{l}\text { 8b- Made up of } 121 \text { amino } \\
\text { acids }\end{array}$ \\
\hline 5. & $\begin{array}{l}\text { Non structural proteins (nsp1, nsp2, } \\
\text { nsp3, nsp4, nsp5, ndp6, nsp7, nsp8, } \\
\text { nsp9, nsp10, nsp11, nsp12, nsp13, nsp14, } \\
\text { nsp15, nsp16) }\end{array}$ & $16 \mathrm{nsp}_{\mathrm{s}}$ & $16 \mathrm{nsp}_{\mathrm{s}}$ & $16 \mathrm{nsp}_{\mathrm{s}}$ \\
\hline
\end{tabular}

Table 2: Summary of SARS- CoV and SARS-CoV-2 accessory proteins and their functions (Narayanan et al., 2008; Liu et al., 2014) ${ }^{20,21}$

\begin{tabular}{|c|c|c|c|}
\hline $\begin{array}{l}\text { Accessory } \\
\text { Protein }\end{array}$ & SARS- CoV & SARS- CoV-2 & Functions in SARS CoV \\
\hline за & present & present & $\begin{array}{l}\text { - Interacts with caveolin-1 during virus uptake and release } \\
\text { - Activates PERK pathway in the UPR } \\
\text { - Activates p38 kinase, NF-kB , JNK and IL-8 production } \\
\text { - Induces RANTES } \\
\text { - Induction of apoptosis and cell cycle arrest }\end{array}$ \\
\hline $3 b$ & present & present & $\begin{array}{l}\text { - Inhibition of Type I IFN production } \\
\text { - Inhibition of Mitochondrial antiviral response } \\
\text { - Inhibition of signalling } \\
\text { - Induction of apoptosis } \\
\text { - Cell cycle arrest }\end{array}$ \\
\hline p6 & present & present & $\begin{array}{l}\text { - Stimulates DNA synthesis } \\
\text { - Suppresses the expression of co-transfected plasmids } \\
\text { - Type I IFN production and signaling inhibition. }\end{array}$ \\
\hline $7 a$ & present & present & $\begin{array}{l}\text { - Host translation inhibition } \\
\text { - Apoptosis induction and cell cycle arrest. } \\
\text { - Activates NF-kB and JNK for IL-8 and RANTES } \\
\text { - } \text { production }\end{array}$ \\
\hline $7 \mathrm{~b}$ & present & present & - Function not characterized fully probably helps in replication \\
\hline $8 a$ & present & - & - Induces caspase-dependent apoptosis \\
\hline $8 \mathrm{~b}$ & present & present & $\begin{array}{l}\text { - Stimulates cellular DNA synthesis } \\
\text { - Undergo ubiquitination. }\end{array}$ \\
\hline $9 b$ & present & present & - Induces caspase-dependent apoptosis \\
\hline orfi4 & - & present & - Function not known \\
\hline
\end{tabular}


Table 3: Summary of drugs experimented for treatment of SARS- CoV-2

\begin{tabular}{|c|c|c|c|}
\hline Drugs & Mechanism of action & Dose used in clinical trials & References \\
\hline \multicolumn{4}{|l|}{ Antiviral Agents } \\
\hline Lopinavir/Ritonavir & 3 CL protease & $\begin{array}{l}\text { (40o/10o mg orally every } 12 \text { hours for } 14 \\
\text { days }\end{array}$ & $59,69,70,71$ \\
\hline Remdesivir & RNA polymerase inhibitor & $\begin{array}{l}200 \mathrm{mg} / \text { dose OD IV for } 1 \text { day followed by } \\
100 \mathrm{mg} / \text { dose OD IV for the next } 4-9 \text { days }\end{array}$ & 72 \\
\hline Favipiravir & RNA polymerase inhibitor & $\begin{array}{l}1600 \mathrm{mg} / \text { per dose (orally) twice in a day } \\
\text { for day } 1 \text {, followed by } 600 \mathrm{mg} / \text { dose (orally) } \\
\text { twice in a day until the end of the trial }\end{array}$ & 73 \\
\hline Oseltamivir ${ }^{*}$ & Neuraminidase inhibitor & $\begin{array}{l}300 \mathrm{mg} \text { orally daily, } 75 \mathrm{mg} \text { orally once or } \\
\text { twice daily, and } 4-6 \mathrm{mg} / \mathrm{kg} \text { orally (fre- } \\
\text { quency not specified). }\end{array}$ & 74 \\
\hline \multicolumn{4}{|l|}{ Immunomodulatory drugs } \\
\hline Chloroquine phosphate & $\begin{array}{l}\text { Inhibition of of viral entry by } \\
\text { preventing glycosylation of host } \\
\text { receptors, } \\
\text { proteolytic cleavage, and endo- } \\
\text { somal acidification. Modulation } \\
\text { of mmunogenic response by in- } \\
\text { hibiting cytokine production. In } \\
\text { addition inhibition of autophagy } \\
\text { followed by lysosomal activity in } \\
\text { host cell occurs }\end{array}$ & $\begin{array}{l}500 \mathrm{mg} / \text { dose (orally) } 2 \text { times in a day for } \\
\text { not more than } 10 \text { days }\end{array}$ & $76,77,78$ \\
\hline Hydroxychloroquine sulfate & $\begin{array}{l}\text { Mechanism same as of Chloro- } \\
\text { quine mechanism of action as } \\
\text { chloroquine }\end{array}$ & $\begin{array}{l}200 \mathrm{mg} / \text { dose (orally) thrice in a day for } 5 \\
\text { days }\end{array}$ & $75,77,80$ \\
\hline Chloroquine+ Azithromycin & $\begin{array}{l}\text { In addition to effect of chloro- } \\
\text { quine, azithromycin probably } \\
\text { alleviate inflammation and mod- } \\
\text { ulate the immune system }\end{array}$ & $\begin{array}{l}\text { Hydroxychloroquine: } 200 \mathrm{mg} \text { (orally) } \\
\text { thrice in a day for } 10 \text { days; Azithromycin: } \\
500 \mathrm{mg} \text { (orally) for day } 1 ; 250 \mathrm{mg} \text { daily for } \\
\text { next } 4 \text { days }\end{array}$ & 79 \\
\hline \multicolumn{4}{|l|}{ Antiinflammatory drugs } \\
\hline Tocilizumab & IL-6 receptor Inhibition & $\begin{array}{l}\text { 4-8 } \mathrm{mg} / \mathrm{kg} \text { intravenous diluted in normal } \\
\text { saline(single dose) }\end{array}$ & 81,82 \\
\hline Sarilumab & IL-6 receptor Inhibition & Single dose Intravenous & 83 \\
\hline \multicolumn{4}{|l|}{ Immunoglobulins } \\
\hline $\begin{array}{l}\text { Immune Globulinn (IGIV, } \\
\text { IVIG, } \gamma \text {-globulin) }\end{array}$ & $\begin{array}{l}\text { Provide passive immunity, sup- } \\
\text { press } \\
\text { the virus and modulate the } \\
\text { immune response to } \\
\text { COVID-19 infection }\end{array}$ & $0.3-0.5 \mathrm{~g} / \mathrm{kg}$ daily for $3-5$ days & 84 \\
\hline
\end{tabular}

